E International

Meeting Society's Transport Needs Under Tight Budgets

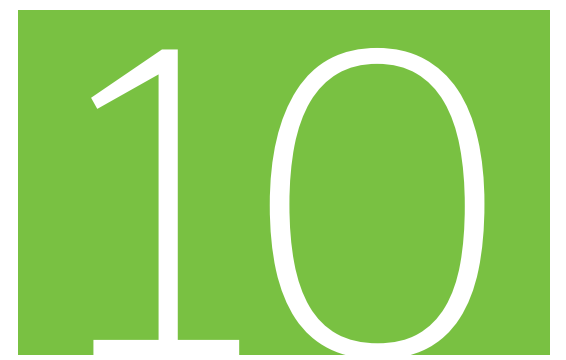

Discussion Paper 2011 • 10 
This document was produced as background for the 2011 International Transport Forum, on 25-27 May in Leipzig, Germany, on Transport for Society. The views expressed in this document do not necessarily reflect those of the member countries of the International Transport Forum.

Further information about the International Transport Forum is available at www.internationaltransportforum.org 


\section{MEETING SOCIETY'S TRANSPORT NEEDS UNDER TIGHT BUDGETS}

Discussion Paper No. 2011-10

International Transport Forum at the OECD, Paris

April 2011 


\section{INTERNATIONAL TRANSPORT FORUM}

The International Transport Forum at the OECD is an intergovernmental organisation with 52 member countries. It acts as a strategic think tank with the objective of helping shape the transport policy agenda on a global level and ensuring that it contributes to economic growth, environmental protection, social inclusion and the preservation of human life and well-being. The International Transport Forum organizes an annual summit of Ministers along with leading representatives from industry, civil society and academia.

The International Transport Forum was created under a Declaration issued by the Council of Ministers of the ECMT (European Conference of Ministers of Transport) at its Ministerial Session in May 2006 under the legal authority of the Protocol of the ECMT, signed in Brussels on 17 October 1953, and legal instruments of the OECD.

The Members of the Forum are: Albania, Armenia, Australia, Austria, Azerbaijan, Belarus, Belgium, Bosnia-Herzegovina, Bulgaria, Canada, Croatia, the Czech Republic, Denmark, Estonia, Finland, France, FYROM, Georgia, Germany, Greece, Hungary, Iceland, India, Ireland, Italy, Japan, Korea, Latvia, Liechtenstein, Lithuania, Luxembourg, Malta, Mexico, Moldova, Montenegro, Netherlands, New Zealand, Norway, Poland, Portugal, Romania, Russia, Serbia, Slovakia, Slovenia, Spain, Sweden, Switzerland, Turkey, Ukraine, the United Kingdom and the United States.

The International Transport Forum's Research Centre gathers statistics and conducts cooperative research programmes addressing all modes of transport. Its findings are widely disseminated and support policymaking in Member countries as well as contributing to the annual summit.

\section{DISCUSSION PAPERS}

The International Transport Forum's Discussion Paper Series makes economic research, commissioned or carried out at its Research Centre, available to researchers and practitioners. The aim is to contribute to the understanding of the transport sector and to provide inputs to transport policy design. The Discussion Papers are not edited by the International Transport Forum and they reflect the author's opinions alone.

The Discussion Papers can be downloaded from: www.internationaltransportforum.org/itrc/DiscussionPapers/jtrcpapers.html

The International Transport Forum's website is at: www.internationaltransportforum.org for further information on the Discussion Papers and other JTRC activities, please email: itf.contact@oecd.org 


\section{TABLE OF CONTENTS}

MEETING SOCIETY'S TRANSPORT NEEDS UNDER TIGHT BUDGETS 5

1. TRANSPORT, GROWTH AND DEVELOPMENT …................................................ 7

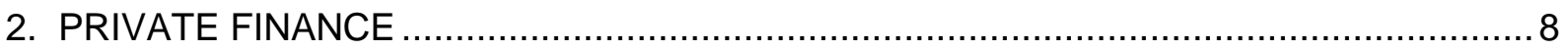

3. THE ROLE OF THE STATE IN PROVIDING AFFORDABLE MASS TRANSPORT SERVICES

4. SUBSIDIES AND CHANNELLING SUPPORT TO DISADVANTAGED USERS

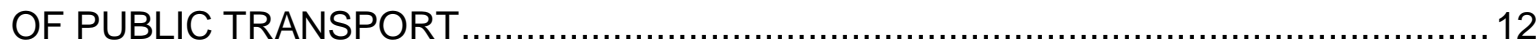

5. ORGANISING PUBLIC TRANSPORT SERVICES …............................................. 14

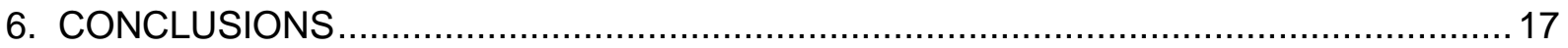

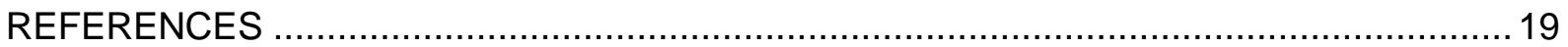





\section{MEETING SOCIETY'S TRANSPORT NEEDS UNDER TIGHT BUDGETS}

In the aftermath of the 2008 financial crisis, both the private and public sectors face stringent constraints in funding for transport infrastructure investment and transport services. At the same time, economic recession highlights the social value of public support for disadvantaged users of transport services and more generally the importance of effective transport systems to efficient labour markets and access to jobs. This drives governments to focus anew on efficiency in the delivery of transport services and infrastructure investments and on efficient targeting of support for public transport. In developing economies these policy concerns are amplified by rapid urbanisation, which makes coordination of transport services across metropolitan areas imperative.

These issues were examined at a roundtable convened by the International Transport Forum and hosted by the Ministry of Communications and Transport of Mexico on 8 March 2011. The programme of the roundtable follows, with presentations available on the web at http://internationaltransportforum.org/Proceedings/Mexico2011/index.html . This paper summarises the discussions.

Roundtable Programme:

- Opening presentation, Felipe DUATE Undersecretary of State for Transport, Mexico

- Private-sector participation (public-private partnerships) in providing quality transport services for transport users, including criteria for selecting investments and projects to benefit the sectors with the greatest need for development, in light of budget constraints.

- Mateu TURRÓ CALVET: Scientific Director for Transport Financing, Centro d'Innovació del Transport, Spain.

- Alfonso BARONA, Director North America Business Development, CINTRA

- The State's role in providing affordable mass transport services for low-income population segments. The suitability of transport subsidies.

- Robert CERVERO, Professor of City and Regional Planning, University of California Berkeley, USA

- Kazuo INABA, Assistant Vice-Minister for International Affairs, Ministry of Land, Infrastructure, Transport and Tourism, Japan

- Alternative modes of transport to benefit the environment. International experiences with mass passenger transport and non-motorised transport

- Adriana LOBO, Director, Centro de Transporte Sustentable Mexico

- Wojciech SUCHORZEWSKI, Warsaw University of Technology, Poland 
- Support from international banks to finance projects in light of cutbacks in funding for transport infrastructure construction and maintenance.

- Manuel ALBORNOZ, Inter-American Development Bank.

- Concluding remarks, Jack SHORT, Secretary General, International Transport Forum. 


\section{TRANSPORT, GROWTH AND DEVELOPMENT}

Access to employment and services (shops, education, health care, etc.) is fundamental to economic activity and to well-being. Motorised transport greatly extends the range of accessible opportunities, facilitates competition, which generally reduces costs and raises the quality of goods, and creates thicker labour and product markets. As a large and growing majority of the world's population lives in cities, urban planning and coordinated public transport systems are critical to accessibility. Attention to the pedestrian environment can greatly enhance access, as walking comprises the first and last legs of the majority of trips. Clear urban strategy, to determine how we want cities to develop, rather than simply responding to short term issues, is critical to growth as well as to the welfare of urban populations. For transport policy this means not only focusing on the highway investments that show the largest returns as, in isolation, highway expansion cannot solve congestion where space is constrained.

Where transport is a bottleneck to economic growth, because of congestion or poor quality infrastructure, investments in transport do yield very large returns. Away from bottlenecks, transport investments have much less of an impact on economic growth (Leunig, 2011). Rapidly developing economies, such as Mexico, present many opportunities for transport investments with high returns. The key in such circumstances is to identify where returns are highest for the limited funding available (ITF 2010). The developing country economies, currently averaging 6\% annual GDP growth, will be the motor of world growth this decade and transport is often a key limiting factor for growth in these countries and for regional trade.

Transport has to be market-oriented to be sustainable. The bulk of transport sector activity is commercial and financing will be needed from the private sector to meet demand for higher quality services. At the same time parts of the sector require public intervention to ensure efficient outcomes; this includes expenditure as well as regulation. Public money is best reserved for areas where risks related to government policies are higher. This includes some urban public transport systems where tariffs are subject to government control. A balance of private and public sector investment is indicated and for this the legal framework needs to provide certainty.

\section{Economic Development Policy in Mexico}

Economic policy in Mexico aims to provide the certainty required for balanced transport sector investment through a focus on four areas:

- Macroeconomic stability for innovation and reducing investment risk.

- Efficient markets with free trade and free investment flows.

- Alignment of government policies between municipal, state and federal levels.

- Generating public goods, including transport and other public infrastructure investment.

To facilitate investment in infrastructure, planning requirements and environmental permit procedures are being simplified and a public investment agency has been established. The aim is to develop intelligent regulation. 
Regional equity is an important criterion in determining priorities for transport infrastructure investment. This is apparent in developing countries, where a balance has to be struck between expenditure on urban and inter urban highways (that show high rates of return), on the one hand, and expenditure on making rural areas currently dependent on un-surfaced roads more accessible year-round. Regional equity is also a critical policy concern in developed countries, for example in the objectives of the European Union to achieve cohesion through investment to ensure peripheral areas have good quality access to economic centres.

Coordination of investment priorities is often complicated by what are seen as acquired rights in public sector companies and perceived grandfather rights by private investors and transport service operators. Such legacy positions can hamper efficient investment and be a drag on adaptation to changing demographic and economic conditions. The development of many large metropolises is impaired by failures to provide coordinated public transport services, with routes and timetables that lack planning and no arrangements for common ticketing and information systems between operators covering different parts of the city or managing different modes of transport.

Figure 1. The Coordination Problem

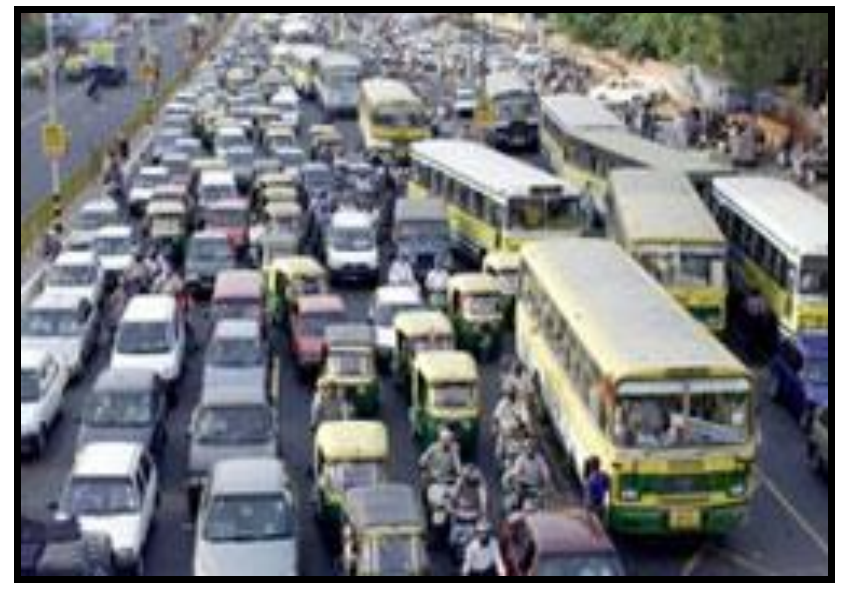

Source: Cervero 2011 (ITF Presentation).

\section{PRIVATE FINANCE}

Much transport infrastructure shares the characteristics of public goods and natural monopoly. Over much of the road network it is expensive or impossible to restrict access for the purpose of making users pay at the point of use. Competition between overlapping road and rail networks is not always feasible. The incentive for un-regulated private suppliers in these circumstances would be to restrict supply and charge well above marginal cost, reducing overall welfare. Policies to ensure equitable access to jobs and services also require transport systems to be provided beyond commercially viable core networks in both urban and rural environments. Most governments have therefore created regulatory frameworks for the provision of transport 
infrastructure and services by private operators that are more optimal from a social welfare perspective. Typically these contract for infrastructure or services under long term concessions and sometimes establish an independent regulator to oversee the development of the economic relationship between the government and private providers over the long term (ITF 2011). Such arrangements cover road networks, passenger dominated railways, metros and buses, and in some countries ferry and air services to peripheral regions.

Government policies in most countries ensure that some transport services are charged below cost, either through compensated public service obligations or through implicit crosssubsidy. Governments often deliver such transport services through publicly owned and operated companies. This arrangement has a number of attractions in simplifying delivery, avoiding transaction costs and reducing the costs of finance; government can often raise funds for capital investment at lower interest rates than the private sector because of its capacity to use tax receipts or to guarantee borrowing against future tax revenues. There are also potential disadvantages to this approach. Consistency of policy is difficult to ensure over the long term given the inevitable changes in short term priorities of elected governments and conflicts of interest can arise between the long term and short term interests. State-owned companies are also prone to capture by politicians and by their workforces. The legacy rights described above tend to undermine the efficiency of public provision. Public companies have sometimes been used to disguise state debts, a frequent problem in the funding of State-owned rail companies where deficits, from under-funded public service obligations and maintenance requirements, have accumulated.

Developing economic regulatory frameworks that use a contract between the public and private sectors to minimise these problems and improve transparency and accountability has been the focus of much research and policy development in OECD countries over the last three decades. Beyond creating a contractual framework for delivering services, private sector involvement can also bring useful experience of project management in a competitive environment to public sector investments. Private concessions have successfully brought transparency to funding arrangements in many such cases (see below) although there have also been cases of serious failure resulting in the financial collapse of projects. Private finance initiatives for infrastructure investment can also be misused to shift public spending off the public balance sheet or for justifying politically expedient projects that would otherwise not pass public sector funding rules. Using PPPs in this way to meet public spending limits confuses the objectives of introducing private equity into the provision of infrastructure and undermines efficiency gains (Kay 2011).

The key factors for the success of private investment in transport are a sound project, transparency and good public sector management of the relationship with the private partner. There is a need for real cooperation and the public partner has to have the resources in skilled personnel to be fully engaged in the relationship. No bad project can become a good project through financial engineering. Whilst a good project can be made bad by inappropriate financing arrangements external finance cannot make a bad public project sustainable.

For both private and public projects balanced appraisal of demand, and thus the expected benefits of the project, are central to success. Optimism bias is frequent in the preliminary PPP project proposals, and in many ways a natural result of incentives on all sides to advance the project. It needs to be countered by scenarios that test the forecast demand and cost assumptions made. The private and public sector parties are not equally suited to take on the different categories of risk involved in long term infrastructure projects. Project management risks should be borne by the private partners but demand-side risk, dependent as it is largely on 
overall performance of the economy, is best shared or taken by the government. Risk associated with potential delays in the issue of permits by government is similarly more suited to being covered by the public partner (ECMT 2007, ITF 2008).

Projects in developing countries can carry additional risks where institutional guarantees of property rights are uncertain, or because of large variations in exchange rates. The rates of return on private investment need to be commensurately higher in these circumstances. At the same time demand-side risks may be lower than in more mature economies as a result of much higher overall rates of economic growth. In economies with a record of chronic under-investment in infrastructure, revealed notably by a failure to maintain the quality of existing networks, the most realistic source to make up the funding deficit is the user. This can be implemented through private or publicly managed tolls, or through private road concessions funded by shadow tolls.

Maintenance is not generally a politically attractive investment, but project finance with lifecycle costing can be used to ensure sustained revenue streams for maintenance. In Spain, for example, road assets managed under concessions have been returned to the public sector in excellent condition at the end of concessions, as required under contract. In contrast to such contractual obligations, public sector management of roads is effectively "unregulated". In the US State of Indiana, some public road infrastructure has been transferred to the private sector under concession, with the private operator required to undertake renewals to tackle a past maintenance deficit. This could be an option elsewhere, including other parts of the USA, where more than 70000 bridges (27\% of the total) are categorized as "structurally deficient". To repair all of them will cost more than 188 billion dollars and public budgets are insufficient for the task.

Some transition economies have, however, witnessed a "PPP syndrome" resulting in all investment going to building new roads, railways and metros, with maintenance ignored. In Poland, for example, it is estimated that 24 times existing the rate of existing expenditure is needed for adequate maintenance of the railways (Source check Suchorzewski). This reflects the belief of policy makers that the electorate wants to see progress made evident through new infrastructure.

The problem of "vanity projects" diverting resources from routine maintenance is widespread. Project evaluation procedures might be used to filter out vanity projects with the lowest returns through an initial screening to classify investments as: A clear returns; B viable, and the focus for arbitrage with other projects; C junk grade. This might help cut out the worst projects. Proposals for operating subsidies might be assessed in a similar way.

A coherent infrastructure investment plan, with clear criteria, can assist in ensuring that scarce funds are channelled to strategic projects. Canada's Building Canada Plan and Canada's Gateways initiative are examples. The plan also includes particular criteria for whether PPPs should be considered under given circumstances. In addition, Canada has also created a state-owned company specifically for promoting PPPs. ${ }^{1}$

1 See www.buildingcanada-chantierscanada.gc.ca/index-eng.html, www.p3canada.ca/home.php and www.canadasgateways.gc.ca/index2.html. 
Another source of financing for transport infrastructure, and urban public transport systems in particular, is to capture the increase in property values created by transport investments and earmark it for funding those investments. This can be achieved through systems of land value taxation (with the rate of the local property tax re-assessed annually on the basis of property prices and commercial rents) or through long term commercial concessions for land use around stations as they are developed. This is the model used by the MTR metro system in Hong Kong. It is particularly suited to extension of cities through greenfield site development and provides sustainable finance, reduces property speculation and results in more transit-centred city design.

\section{THE ROLE OF THE STATE IN PROVIDING AFFORDABLE MASS TRANSPORT SERVICES}

Over-dependence on private, road passenger transport tends to excludes from society the elderly, infirm and others with limited or no access to cars. There is a right to mobility/access that needs to be respected and provided for. Public transport can also produce positive spillovers in terms of fuel savings, emissions reductions and congestion relief in the right circumstances. All these factors should be taken into account in public policy. Expenditure on public transport has opportunity costs as money could instead be spent on, for example, education or hospitals. It also competes with expenditure on other transport projects. The quality of project assessment is critical in determining which projects to invest in (ITF 2010, ITF 2011b).

Public transport can be particularly important in providing mobility for low income households, although it is not always the poor that benefit most. In developing countries in particular, the poorest sections of society often cannot afford even subsidised fares. Poor coordination of collective transport services is a widespread problem in this respect, increasing the cost of end-to-end journeys as well as the time required to reach destinations. Areas of low cost housing, as well as shanty towns, often lie beyond city limits and require multiple transfers for the journey to work. In Mexico City, for example, this typically includes a bus ride outside city limits (regulated fare 8 pesos), a trip on a regulated bus inside the city limits (4.5 pesos) or an unregulated para-transit ride ( 2 pesos and up depending on distance), plus a metro trip ( 3 pesos flat fare). The sum cost for a return trip can easily exceed $25 \%$ of the minimum wage (60 pesos a day). The absence of integrated public transport planning and ticketing thus severely penalises the section of the population that lives in these areas. As a rule of thumb no more than $15 \%$ of income should be spent on commuting by low income households for social sustainability (Armstrong-Wright 1986). Up to $25 \%$ of the income of poorer residents in the greater Mexico City area is spent on transport (Cervero 2011).

Some public transport investments, and BRT systems in particular, have transformed access to jobs and services for the poor. One example is the Transmileneo project in Bogota. This was designed as part of an integrated urban development plan to reclaim public space in the city and re-house shanty dwellers in greenfield locations well-served by affordable public transport. BRT routes connecting these areas to the centre of the city are supplemented by freeof-charge feeder bus services. The City of Medein, also in Colombia, transformed accessibility for the poor with integrated tariffs for metro, BRT and metrocable systems. The latter are cable cars to link mountain-side favelas to metro and BRT stations, serving existing poor areas in-situ. 
Household surveys of Rio de Janeiro have shed some light on the distribution of benefits from different public transport policies. For the very poor, subsidised bus services provide much bigger benefits than deregulating bus services or relying on the informal bus sector to provide services, principally because in both the latter cases fares are higher. For middle class households the outcome is more or less opposite.

\section{SUBSIDIES AND CHANNELLING SUPPORT TO DISADVANTAGED USERS OF PUBLIC TRANSPORT}

Where the private sector operates public transport services intervention is often required to achieve the range of services sought by policy makers. Unaided, the private sector is constrained to cut non-profitable services, which characterise off-peak periods and services in extra-urban areas. These services are often of disproportionate value to low income workers as they often have irregular working hours.

Concessionary rates for using public transport are most often funded through crosssubsidies, with the effect that one segment of relatively low income population transferring income to another poor segment. Cross-subsidies also undermine the financial viability of public transport operations. The burden of concessionary fares ought instead to be passed on to social service budgets in the interests of the financial sustainability of transport operations.

Revenues can be increased, in the interests of financial sustainability, by differentiating fares. Peak pricing is the main route, and tends to affect the poorest users less than other groups because travel to non-office jobs is more likely to be outside of the peaks. Smart cards offer more opportunities for differentiation. Ageing of the population is an increasingly important factor but not all older users are poor; subsidies should thus not be provided to those that are not economically disadvantaged. In principle, better value for money can be obtained by a switch to voucher type support to poor households to cover their transport costs. This enables public transport operators to maintain fares at a level that provides for financial sustainability. It also avoids the common problem that low fares translate into poor services, which drives higher income users to use cars instead. Even low income users are sometimes more sensitive to service than price. The ideal policy package first puts money into the pockets of the poor through vouchers and then opens up the market to competition

Japan has developed a largely successful, targeted approach to supporting access to public transport services for disadvantaged users, including students, the elderly, car-less households and welfare recipients. There are fare reduction programs but fare price is not usually the main issue. Maintaining the provision of services outside of core areas and compensating for an absence of services in some lower density areas is the bigger problem.

Concessionary fares for commuter passes are funded by employers and for senior citizen passes the general tax payer pays. Only in other cases do other users pay through crosssubsidies. Welfare recipients are eligible for free passes funded by the municipal government in Tokyo although this does not apply in other cities, where municipalities are less directly involved in bus provision. 
Community buses are used to extend networks beyond core bus routes. These provide critical services for elderly people in peripheral areas, providing access to hospitals, shopping areas and railway stations, the main destinations for users of these services. With the ageing of the population, widows are now the largest category of passengers on community buses and are typically either too old to drive or have never driven, having previously relied on a husband for mobility.

Figure 2. Community Bus in Japan

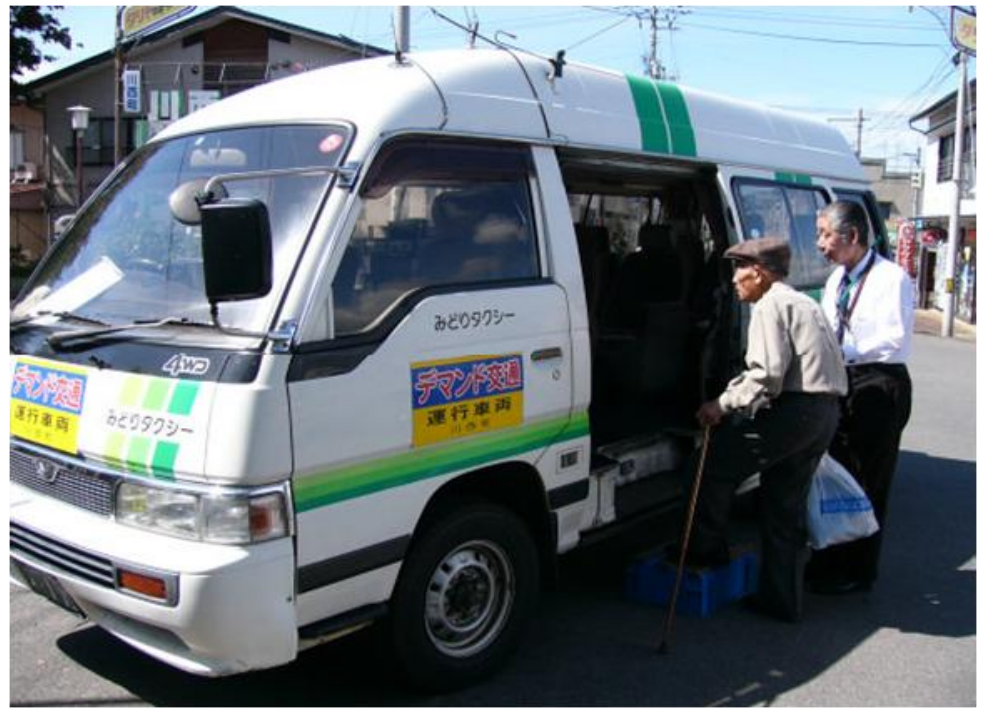

Source: Inaba 2011 (ITF Presentation)

No subsidy or other public support is provided to Japanese railway or metro operations; public expenditures are channelled in this sector to infrastructure only. Bus services can receive up to $40 \%$ of operating costs in public subsidy. When still not profitable with this level of subsidy, operators of bus concessions can abandon services but are required to negotiate with government for up to one year to find alternative mobility solutions. A city administration might then introduce a community bus service, eligible for a $50-80 \%$ subsidy.

In other cases community services are only introduced in response to an initiative from a local community group. The continuation of community services begun in this way is often made conditional on keeping up a minimum level of ridership, which serves as an incentive for groups demanding services to use them regularly once introduced.

Subsidies are becoming an increasing financial burden on municipal budgets. The key to continuing services is therefore efficiency. To this end many regular, school and on-demand bus services have been integrated into new style on-demand bus services. This has enabled costs to be cut and services maintained in many cases. It should be noted that leadership by dedicated individuals has usually been the determining factor in the success of community and on-demand services in Japan. Efficiency is the key to financially sustainable services everywhere, and a number of other countries have experience in successfully combining local services that can no longer be funded separately (White 2011)..

In Poland in the 1990s policies were adopted to reduce subsidies for public transport, with a view to abandoning services when subsidies reached $80 \%$ of operating costs. Subsidies were 
cut but are still unsustainable, with $50 \%$ of costs now covered by the fare box and $50 \%$ by cities budgets. In Western Europe subsidies are higher than this but public finances are not as stretched as in Poland.

\section{ORGANISING PUBLIC TRANSPORT SERVICES}

The structure of public transport tends to be inefficient in metropolises that lack coordinated planning, like Mexico City, resulting in inefficient competition between an excess of bus and para-transit routes concentrated on the main axes. Coordination of routes and interconnections is needed, often under a regional transport authority. An independent regulator can be useful in this role to restructure routes and let concessions, ensuring that domination by a private monopoly is avoided. Coordinated restructuring can both improve services and cut costs, allowing for investment in integrated ticketing technology and possibly a reduction in subsidies. Such systematic restructuring can also provide the opportunity for creating priority lanes for buses.

Germany's Verkehrsverbund are an example of good practice in coordinating services. These are executive boards of managers from each transport operating company that pool income and set productivity incentives. Revenue is distributed on the basis of performance. 
Figure 3. Integrated Services and Tariffs - A Swiss Example

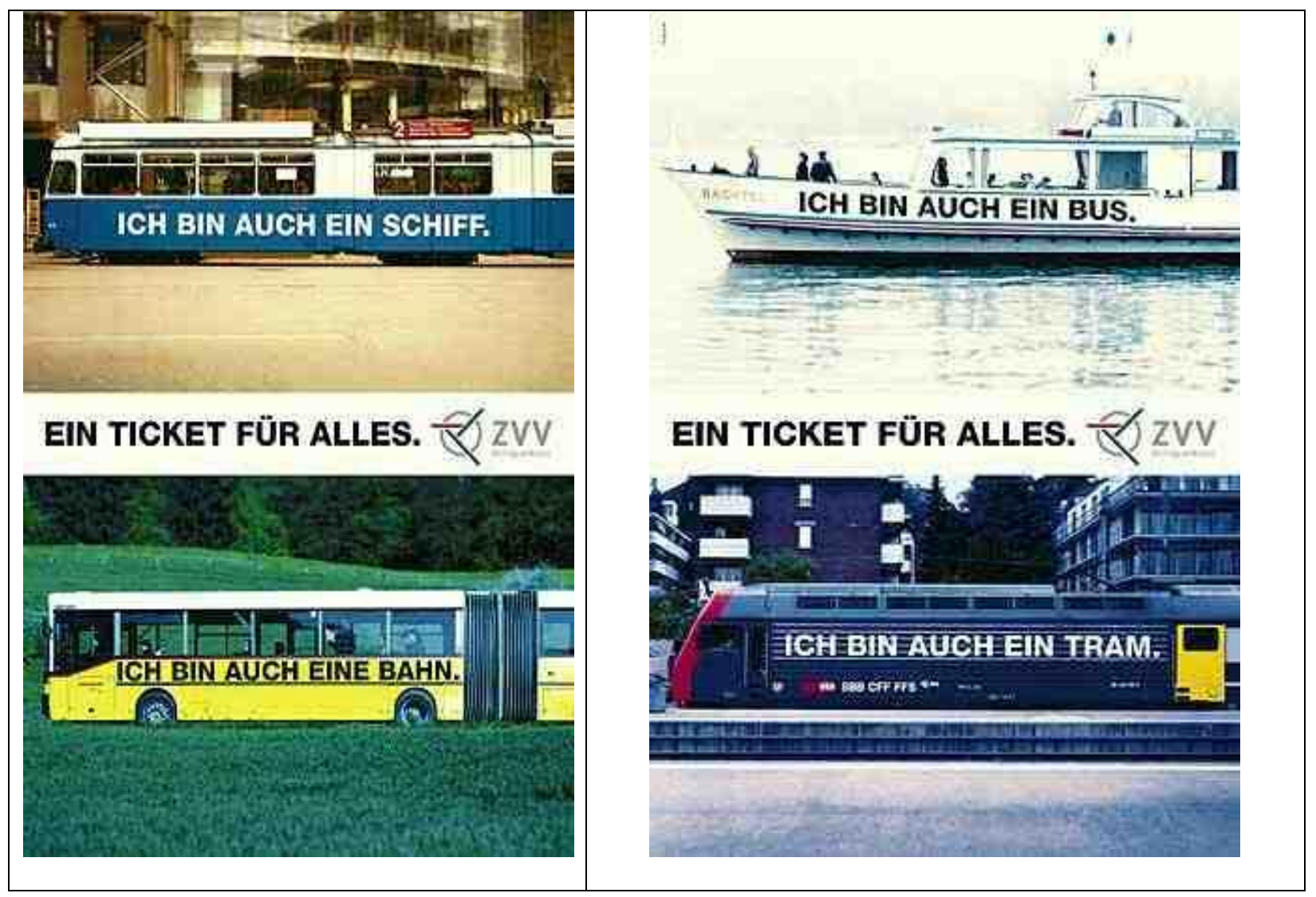

Source: Cervero 2010.

The European Union has highlighted the importance of improving efficiency to financial sustainability, and put competitive tendering for concessions centre stage with regulation 1370 of 2007 on Public Passenger Transport Services by Rail and by Road. The preamble to the regulation states that the introduction of regulated competition between operators leads to more attractive and innovative services at lower cost. The use of such concessions has brought down costs and increased transparency in the financing of public service obligations in a number of European countries.

Some negative consequences have been observed in countries with a decade or more of experience with concessions. In Sweden, the $3^{\text {rd }}$ and $4^{\text {th }}$ rounds of concessioning saw costs increase following earlier savings, and research and development has been stripped out of the operating companies. Contracting for the minimum, without providing for funding of R\&D, might thus have been a mistake. More generally, awarding concessions primarily on the basis of lowest cost can be damaging for services.

Much of the public subsidies that are provided to public transport leaks into better conditions for workers in the sector rather than providing better services. This problem is generally reduced around $50 \%$ by the use of public concessions to private operators to operate the services under compensated public service obligations (Pickrell 1985, Cervero 1986). 
Para-transit (unregulated transport by minibus, pickup truck or similar vehicles) is a particular issue in developing and transition economies. It provides a large share of service in many cities and has the virtue of flexibility. However, it is difficult to regulate and tends to result in a concentration of operations on trunk routes and poor coverage elsewhere. Para-transit has taken over the sector in some countries of the former Soviet Union where trams have been abandoned, for example in Yerevan where most operators are unlicensed. In such circumstances safety is also difficult to regulate and standards tend to be very low. In some of the new EU Member States, para-transit has grown but is licensed, with vehicles registered and inspected and routes regulated (but with no concession payment).

Figure 4. Unregulated Para transit

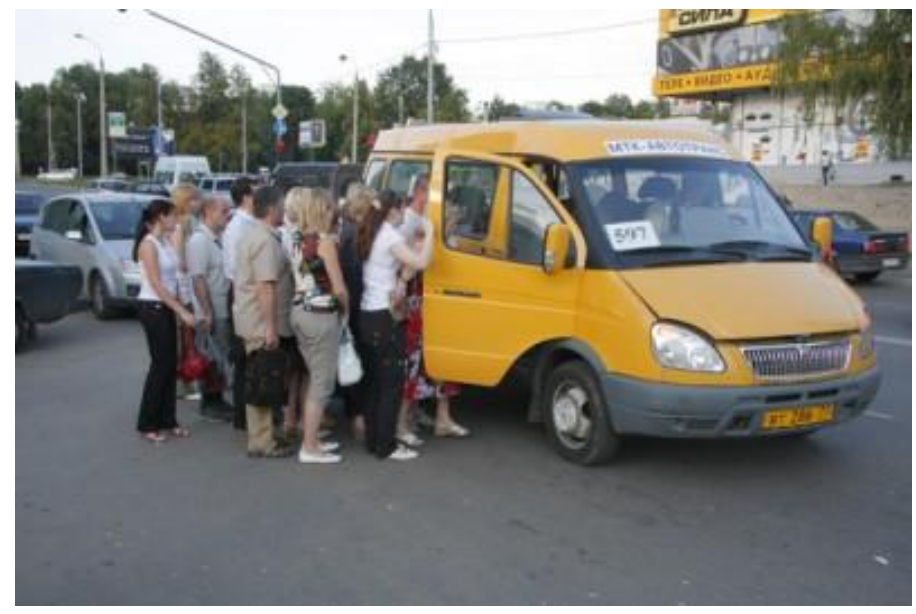

Source: Suchorzewski 2011 (ITF Presentation)

The choice of public transport systems to invest is not always straightforward in large middle-income cities. There is a place for para-transit, but it needs to be regulated and integrated into regional public transport planning. Regulated buses are a core part of an efficient system. When incomes are high enough to cover a sufficient share of cost from the fare box for financial sustainability, and where demand is high, metro systems can provide the higher capacity, higher speeds and more reliable travel times needed. This comes at a cost, with metro systems costing 3 to 6 times the cost of buses. BRT systems offer an intermediate solution that can deliver reasonably fast, fairly high capacity services at reasonable cost, although they cannot match the capacity of metro systems and do compete with other modes of transport for road space (see accompanying figure). 
Figure 5. Commercial Operating Speeds versus Capacity for Different Public Transport Modes

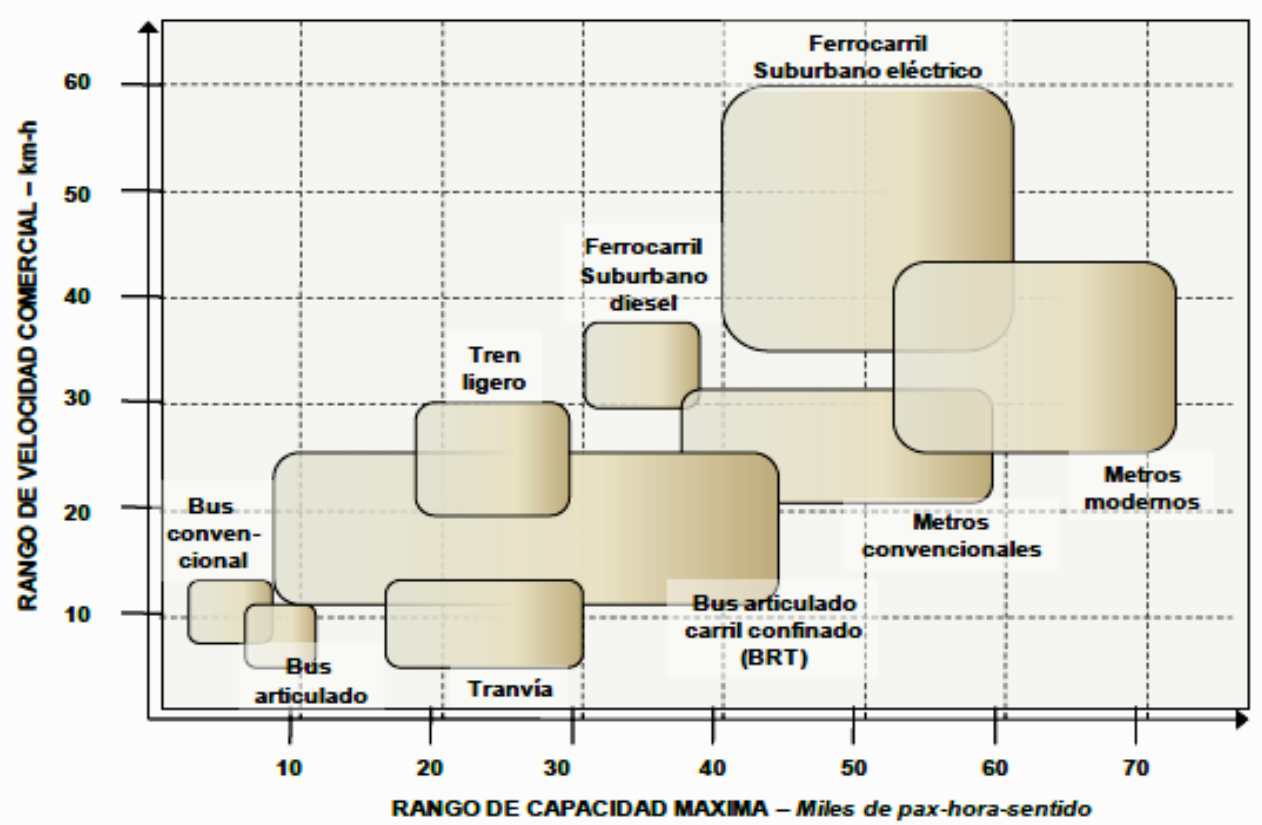

Source: Lobo 2011 based on Vuchic 2005.

\section{CONCLUSIONS}

Rescuing the banking sector has resulted in public sector spending cuts in many member countries. This increases pressure to obtain value for money from public expenditure on transport services. Under effective regulatory frameworks, the private sector can help secure efficiencies and there is an appetite for investment in sound projects despite the priority currently given to recapitalisation by many financial institutions. The importance of the key criteria for successful PPPs - assigning risks appropriately between public and private partners and creating constructive incentives that minimise optimism bias - are underscored by the financial crisis. Both parties currently focus on minimising their exposure to all risks. Project risk (delays from project management and organisation, procurement costs) belongs with the private partner, whilst demand risk and risk related to planning permits can be better managed by Government.

Subsidies to infrastructure and the operation of public transport systems are widespread but need to show value for money. Competitive tendering of concessions for services is useful in containing costs, but service quality may suffer if tendering over-emphasises cost minimisation. Subsidies to operators to provide services to the poor should be funded from welfare budgets rather than through cross-subsidy from one user group to another within the transport concession. A shift to supporting disadvantaged public transport users through vouchers instead 
of subsidies to operators would allow fares to rise, improving the financial sustainability of services and avoiding deterioration of services. Even users on low incomes are highly sensitive to quality of service. And even in high average income countries like the USA a significant part of the population has no access to cars and is dependent on efficient public transport.

Integrated planning of public transport services across metropolitan regions and their outlying feeder areas is essential to efficiency and to ensuring comprehensive access to transport for work. Integrated fares between zones and between modes (buses, BRT, metros, rail) are vital to containing the costs of journeys to work and making public transport viable at the network level. Regional coordination and regulatory institutions are usually needed for achieving integrated fares and integrated planning.

Finally, attention to pedestrian and cycling environments, and the suitability of pavements and vehicles for users with impaired mobility, can greatly enhance access and is essential for ensuring seamless initial and final legs for the majority of urban journeys. Reclamation of public spaces from unregulated parking, unregulated para-transit depots and unregulated markets has been an important part of integrated urban transport and planning projects such as the Transmilenio in Bogota.

\section{Figure: Public Cycling Provision to Complement Public Transport in Mexico City}

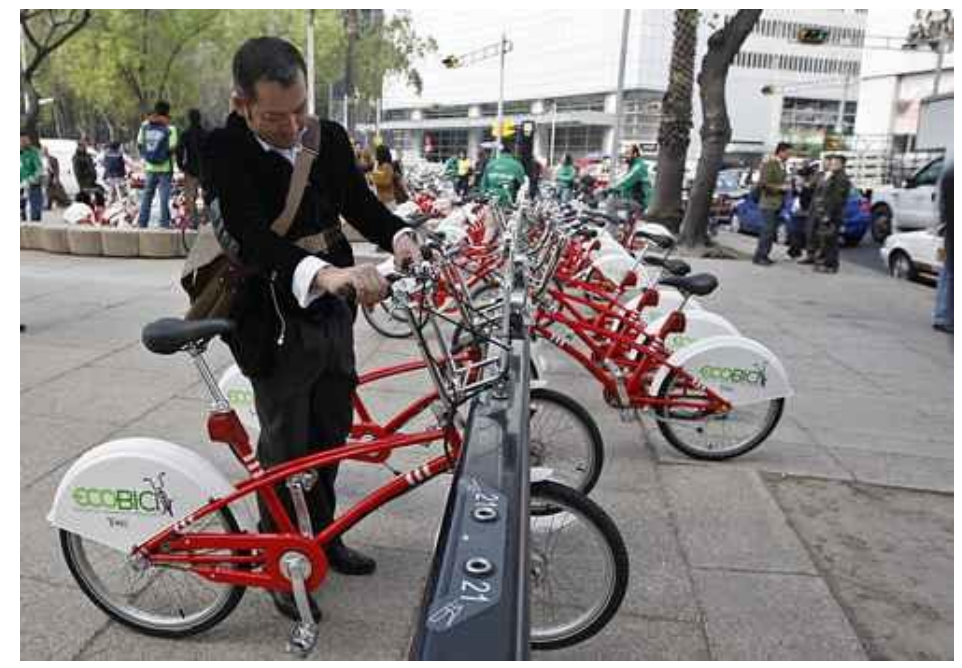

Source: Lobo 2011 (ITF Presentation). 


\section{REFERENCES}

Armstrong-Wright 1986, A. Armstrong-Wright. Urban Transport Systems: Guidelines for Examining Options. World bank Technical Paper, Urban Series No. 52, Washington, D.C.

Cervero 1986, Robert Cervero, Examining the performance impacts of transit operating subsidies, ASCE Journal of Transportation Engineering 115 5, pp. 467-480.

Cervero 2011, Robert Cervero, The State's Role in Providing Affordable Mass Transport Services for Low-Income Residents, ITF Discussion Paper 2011, http://internationaltransportforum.org/Proceedings/Mexico2011/Cervero.pdf

ECMT 2007, Competitive Tendering of Rail Services, OECD Publishing 2007, http://internationaltransportforum.org/itrc/rail/index.html

ITF 2008, Transport Infrastructure Investment: Options for Efficiency, OECD Publishing 2008

http://internationaltransportforum.org/itrc/infrastructure/Investment/07TI1summary.pdf

ITF 2010, Improving the Practice of Cost Benefit Assessment in Transport, Summary and Conclusions of Roundtable, Queretaro, Mexico, Discussion Paper 2011-01, November 2010. http://internationaltransportforum.org/jtrc/DiscussionPapers/jtrcpapers.html

ITF 2011, Better Regulation: The Role of the Regulator, Summary and Conclusions of Roundtable, Paris, ITF Discussion Paper 2011-3 http://internationaltransportforum.org/jtrc/DiscussionPapers/jtrcpapers.html

ITF 2011b, Improving the Assessment of Transport Investments: Accounting for Heterogeneity among Users, ITF Discussion Paper 2011. http://internationaltransportforum.org/itrc/DiscussionPapers/itrcpapers.html

Kay 2011, John Kay, Don't Blame Luck when Your Models Misfire, 03 March 2011, Financial Times,

http://www.johnkay.com/2011/03/03/don\%e2\%80\%99t-blame-luck-when-your-models-misfire

Leunig, 2011, Tim Leunig, Cart or Horse: Transport and Economic Growth, ITF Discussion Paper 2011-4

http://internationaltransportforum.org/itrc/DiscussionPapers/itrcpapers.html

Lobo 2011, Perspectives from Mexico for Achieving More with Less: Alternative Transport Modes and their Social and Environmental Benefits, ITF Discussion Paper 2011-6 http://internationaltransportforum.org/Proceedings/Mexic02011/Cervero.pdf 
Pickrell 1985, Don H. Pickrell, Rising Deficits and the Uses of Transit Subsidies in the United States, Journal of Transport Economics and Policy Vol. 19, No. 3 (Sep., 1985), pp. 281298

Vuchic 2005, Vuchic, Vukan R. 2005, Urban Transit Operations, Planning and Economics,

White 2011, Equitable Access: Remote and Rural Communities' Transport Needs ITF Discussion Paper 2011.

http://internationaltransportforum.org/itrc/DiscussionPapers/jtrcpapers.html 
E International

International Transport Forum

2 rue André Pascal

75775 Paris Cedex 16

itf.contact@oecd.org

www.internationaltransportforum.org 